\title{
Bone Marrow Cell Count Ratio Measurement
}

National Cancer Institute

\section{Source}

National Cancer Institute. Bone Marrow Cell Count Ratio Measurement. NCI Thesaurus.

Code C97567.

The determination of the ratio of one blood cell component to another in a blood sample. The measurement may be expressed as either a ratio or a percentage. 